\title{
An investigation into a link Between Classroom Environment and EFL Student Teachers' Academic Achievement
}

\author{
Mei Afriliani \\ An English Teacher of SMA Muhammadyah Lahat, South Sumatera \\ meiafriliani56@gmail.com
}

Muhamad Holandyah

Faculty of Tarbiyah and Teaching Sciences State Islamic University of Raden Fatah mubammadholandyah_uin@,radenfatah.ac.id

\begin{abstract}
The aim of the present study was to investigate the relationship between classroom environment and academic achievement of English Education Study Program students of State Islamic University of Raden Fatah Palembang by conducting correlational research. 366 students of English majors of the second, fourth, and sixth semester took part in the study as the sample by using convenience sampling. The data of this study were collected by administering a questionnaire of College and University Classroom Environment Inventory (CUCEI) to assess classroom environment of the students and the students' cumulative GPA was also used to get the students' academic achievement score. Pearson Product Moment and regression analysis were used to analyze the data. From the analysis, it was found out that the $r$ was 0.296 and it was higher than $r$-table (0.1059) and the level of probability ( $p$ ) significance (sig.2-tailed) was 0.000. It means that $H_{0}$ was rejected and $H_{1}$ was accepted. This result showed that there was a significant correlation between classroom environment and the students' academic achievement. Additionally, the regression analysis showed that classroom environment contributed only $8,8 \%$ to the students' academic achievement.
\end{abstract}

Keywords: classroom environment, academic achievement, student teachers

\section{Introduction}

In this globalization era, the students in every institution are trained to be academically successful (Azkiyah \& Mukminin, 2017; Mukminin, Rohayati, Putra, Habibi, \& Aina, 2017; Mukminin, Kamil, Muazza, \& Haryanto, 2017). Brockman and Russell (2012) consider thatacademic success is directly linked to the successful outcomes and values for youth in society. Furthermore, Musthaq and Khan (2012), Luschei (2017), and Sánchez-Escobedo and Hollingworth (2017) argue that the social and economic development of the country is directly linked with students' academic performance. Performance is how well or badly something is done. In educational parlance, performance is indicated through academic achievement (Siahi \& Maiyo, 2015). Hisken (2011) defines academic achievement as the level of actual accomplishment or proficiency one has achieved in an academic area, as opposed to one's potential. Therefore, 
the quality of student experiences during college is shown by ones academic achievement (Abrar \& Mukminin, 2016; Luschei, 2017; Haryanto \& Mukminin, 2012; Mukminin, Haryanto, Makmur, Failasofah, Fajaryani, Thabran, \& Suyadi, 2013; Mukminin \& McMahon, 2013).

Academic achievement is important for students to prepare them for future career and to allow students to enter competitive fields. It also plays an important role in producing the best quality graduates who will become great leader and manpower for the country thus responsible for the country's economic and social development (Ali, Mokhtar, \& Kamaruzaman, 2009; Hadiyanto, Mukminin, Failasofah, Arif, Fajaryani, \& Habibi, 2017; Haryanto \& Mukminin, 2012). Moreover, academic achievement serves as a key criterion in order to judge students' true potentials and capabilities (Daulta, 2008; \& Nuthanap, 2007) which can help students in all areas of their lives. Teaching is guiding and facilitating learning, enabling the learner to learn, setting the conditions for learning (Ariesca \& Marzulina, 2016; Azkiyah \& Mukminin, 2017; Mukminin, Rohayati, Putra, Habibi, \& Aina, 2017; Mukminin, Kamil, Muazza, \& Haryanto, 2017). In the teaching and learning process, it can be seen that there is a difference in student's achievement. This is caused by different factors that affect the academic achievement of students (Kamil \& Mukminin, 2015; Mukminin, Ali, \& Ashari, 2015). One of factors that affects students' academic achievement is classroom environment. The classroom is a basic structural unit of our educational system (Talton \& Simpson, 2007). It is a miniature community in which members' interest influences the behavior of others. Vygotsky stated that classroom environment is the culture that can be the place to study and learn about knowledge (as cited in Wei \& Elias, 2011, p. 240). Classroom environment is an embodiment of physical psychosocial conditions. According to Carpenter (2006), physical environment is made up of chairs, desks, tables, lightening, ventilation, space, acoustics and instructional materials, while psychosocial environment refers to the feeling, a type of classroom that has to do with interactions in the classroom. Classroom environment plays an important part of students' educational success (Habibi, Sofwan, \& Mukminin, 2016; Mukminin, Muazza, Hustarna, \& Sari, 2015. Based on Vygotsky's theory of social development (as cited in Wei \& Elias, 2011, p. 240), students' learning development can be determined by the classroom environment because students spend their time to learn mostly in the classroom although learning can take place in other venues. Moreover, Yan (2006) said that for foreign language learners, classroom is the main place where they are frequently exposed to the target language. Therefore, creating a conducive learning environment by providing sufficient classroom environment physically and social psychologically are very important.

Taken into the consideration that classroom environment affects students' academic achievements, the students' perceptions of classroom environment are very important. Therefore, the reason why students failed in some subjects is probably because they are not engagedd in classroom activities sufficiently. The finding of study conducted by Ziegler, Cheryan, Plaut and Metzoff (2014) showed that the physical classroom environment, such as inadequate lighting, noise, low air quality, and deficient heating in the classroom are significantly related to lower student achievement.

Physical environment is not only the main problem that caused poor achievement, but also interaction in classroom. As stated by William (1997) "classroom environment is a dynamic system where students interact each other. It is the place where the interaction between student and student or between students and instructor occur most frequently" (p. 9). According to Dewey (2006), the poor student relationship may lead to poor achievement, while good student/teacher relationship may lead to better achievement. Moreover, Bucholz and Sheffler (2009) revealed that a warm interaction in a classroom environment can lead to increased academic achievement and a sense of pride and belonging in a college. 
Preliminary study was conducted by interviewing students of English Education Study Program of State Islamic University of Raden Fatah Palembang. It revealed that some students enjoyed studying because they felt that classroom was already well-structured, clean enough, conducive lighting, and comfortable air temperature. However, the problem started when the electricity stopped working. The classroom was hot and dark and this bothered the students, especially those who sit on the back. In such situations, the students started feel sleepy, and made some of them lost their focus to fully grasp the lecture. Students also said that they were dissatisfied with their academic achievement because the class sometimes seemed boring and they did not participate in the class as well. This kind of interaction within the class influenced their feeling.

Some researchers have tried to investigate the correlation between students' perception of classroom environment and their academic achievement. Kaur (2001) showed that there was a positive correlation between classroom environment and academic achievement. Temperature and ventilation also affects the classroom learning environment. In the study of Ziegler et al. (2014), it was found out that the building's structural facilities influenced students' achievement. On the other hand, one study did not find relationship between structural condition and student performance in Wyoming (Picus, Marion, Calvo, \& Glenn, 2005). From the explanations above, the aims of the study were to find out: (1) whether or not there was any significant correlation between classroom environment and academic achievement of English Education Study Program Students of State Islamic University of Raden Fatah Palembang, and (2) whether or not classroom environment significantly influenced academic achievement of English Education Study Program students of State Islamic University of Raden Fatah Palembang.

\section{Literature Review}

\section{Classroom environment and academic achievement}

Classroom environment is the place in which teaching and learning process occurs. Akubue (2001) defines the classroom as a base for all types of activities. It holds students together and offers them the opportunities of achieving the purpose of education. A greater part of educational activities of any school or college occurs in this room. Hannah (2013) also describes that classroom is where the student develops what they want their future to look like, as well as knowledge of the skills they need to reach that goal. The classroom environment also defines in terms of the students' and teachers' shared perceptions in that environment (Fraser \& Pickett, 2010). In addition, the classroom is a place for interaction amongteachers, materials and students in order to create students behavior. However, classroom environment has influence in the teaching and learning process. Abrar, Mukminin, Habibi, Asyrafi, Makmur, a Marzulina (2018) state that classroom environment, and negative comments from teachers and peers, may hinder the learners from actively engaging, and eventually make it difficult to speak.

Students' academic achievement refers to the grades obtained by students upon accomplishing the courses in the end of their study of an instructional environment, specifically in school, college, and university. Hisken (2011) defines academic achievement as the level of actual accomplishment or proficiency one has achieved in an academic area, as opposed to one's potential. There were two kinds of academic achievement, GPA (Grade Point Average), which is the students' academic achievement in each semester that students achieve at the end of their college, and Cumulative GPA, which is obtained by having score of each subject from the whole semesters that they already take. 


\section{The relationship between classroom environment and academic achievement}

The role of classroom environment in influencing academic outcomes has been shown by many researchers in recent years (Suleman \& Hussain, 2014; Fraser 1986). The psychosocial environment in a classroom can significantly predict academic achievement (Joanna, 2009). Recent research in retention rates of university students has contributed evidence for the positive relationship between the perception of classroom environment and academic achievement (Mokhtar, 2003). Fraser (1986) asserts that the classroom environment is such a potent determinant of student outcomes that it should not be ignored because students will perform better and have more positive attitudes in learning when they perceive classroom environment positively (as cited in MacAulay, 1990). As reported by Gazelle (2006) that a positive classroom learning environment is closely related to students' enhanced academic achievement. Therefore, it can be said that students' perception of classroom environment will affect students' academic achievement because the students who have the positive perception of their classroom environment will have a high interest with the lesson and it may increase their grades.

\section{Methodology}

\section{Research design}

In this study, correlational research method was used to find out the correlation between variables and interpret the result that may appear. This method was used to find out the correlation between classroom environment and academic achievement of students of English education study program at State Islamic University of Raden Fatah Palembang. Creswell (2005) states that correlation design is procedures in quantitative research in which investigators measure the degree of association (relationship) between two or more variables using the statistical procedure of correlation analysis. Furthermore, Fraenkel, Wallen and Hyun (2012) states that correlational studies investigate the possibility of relationships between only two variables although investigations of more than two variables are common. The procedures were (1) College and University Classroom inventory (CUCEI) questionnaire from Treagust, Frasher, and Dennies (1986) was given to know students classroom environment, (2) the students' academic achievement was obtained by their cumulative GPA, (3) SPSS 16 was used in order to find out the correlation between the variables based on the result of questionnaire and cumulative GPA, and (4) the explanation and interpretation of the results were then discussed.

\section{Research site, sampling, and participants}

The population of this study was all the students of English education study program of State Islamic University of Raden Fatah Palembang in the academic year 2016-2017 which consisted of 580 students. Then, 366 students of English education study program of the second, fourth, and sixth semesters took part in the study as the sample by using convenience sampling.

\section{Data collection}

Before collecting the data, the two instruments in this study were checked for the validity and reliability. CUCEI questionnaire was a ready-made questionnaire and was already validated by Treagust, Frasher, and Dennies (1986). The questionnaire consists of 49 Likert-type items of positive and negative statement and consist of 4 Likert-scale ranging from 1 "strongly disagree" to 5 "strongly agree" (for positive statement), and 5 "strongly disagree" to 1 "strongly agree" (for negative statement). Cronbach alpha of .70 to .90 was obtained. It can be concluded the CUCEI was valid and reliable. Besides, documentation is an objective and reliable measure students' academic achievement. Documentation validity was not checked because it has been validated 
and reliable. To sum up, all the data were able to be used for each correlation and regression analysis.

\section{Data analysis}

Before analyzing the data obtained, normality and linearity test was conducted. If $\mathrm{p}>$ 0.05. If $\mathrm{p}<0.05$, it means the data are not normal. Kolmogorov-Smirnov was used to see the normality. The results of normality indicates that the data from each variable were all normal and appropriate for data analysis with coefficients of .192 for classroom environment and .058 for academic achievement. For linearity test, deviation of linearity was obtained. If probability is higher than .05 , the two variables are linear. The results showed that the deviation from linearity between classroom environment and academic achievement (Sig) was 0.343 or higher than 0.05 which the result was linear.

After all of data were found normal and linier, the correlation and regression analysis were conducted. The results from the instruments of both questionnaire and students' GPA were calculated to find any potential correlation between variables through Pearson Product Moment Coefficient in SPSS with 5\% significant level. Then, the significance of the correlation coefficient is used to determine by comparing the data of the coefficient ( $r$ data) in the level of significance of 5 percent in the table of product moment ( $r$ table). The correlation coefficient is significant if $r$ table in the level of significance of 5 percent less than $r$ data. In addition, according to Cohen, Manion, and Marison (2007), there is a correlation if p-value is higher than 0.20 . In order to know the contribution of classroom environment and academic achievement of undergraduate EFL students' of State Islamic University of Raden Fatah Palembang, regression analysis was applied.

\section{Findings and Discussion}

In this study, two kinds of instruments were used; questionnaire and documentation. First, from the College and University Classroom Environment Inventory Questionnaire, the result of students' classroom environment showed that the maximum score was 220, and the lowest score was 103. The mean of classroom environment scores for the participants was 171.74 and the standard deviation was 18.047. This mean score (171.74) indicated that the level of classroom environment of English Education Study Program students of State Islamic University of Raden Fatah Palembang was in average level. The descriptive statistical analysis of classroom environment for the participants is shown in Table 1 below.

Table 1. Descriptive statistics of classroom environment

\begin{tabular}{crrrrr}
\hline & N & Minimum & Maximum & Mean & Std. Deviation \\
\hline Classroom_environment & 345 & 103 & 220 & 171.74 & 18.047 \\
\hline Valid N (listwise) & 345 & & & & \\
\hline
\end{tabular}

It revealed from the questionnaire that the three levels of classroom environment were perceived by the students. The result showed that 115 students $(33.3 \%)$ were in high category, 208 students $(60.3 \%)$ belonged to average category, and 22 students $(6.4 \%)$ were in low category. The details are described in Table 2 below. 
Table 2. Distribution of students' classroom environment

\begin{tabular}{|c|c|c|c|}
\hline Score Interval & Category & Frequency & Percentage \\
\hline $180-245$ & High & 115 & $33.3 \%$ \\
\hline $114-179$ & Average & 208 & $60.3 \%$ \\
\hline $49-113$ & Low & 22 & $6.4 \%$ \\
\hline \multicolumn{2}{|c|}{ Total } & 345 & $100 \%$ \\
\hline
\end{tabular}

Second, after the documentation of students' academic achievement was obtained, the descriptive statistics showed that the highest cumulative GPA was 4.00 and the lowest was 1.45. The mean of academic achievement for the participants is 3.4503 , and the standard deviation is 0.28468. The distribution of the result of the students' cumulative GPA can be seen in Table 3 below.

Table 3. Descriptive statistics of academic achievement

\begin{tabular}{crrrrr}
\hline & N & Minimum & Maximum & Mean Std. Deviation \\
\hline Academic_Achievement & 345 & 1.45 & 4.00 & 3.4503 & .28468 \\
\hline Valid N (listwise) & 345 & & & & \\
\hline
\end{tabular}

After collecting the result of students' academic achievement, I then categorized the students based on their cummulative GPA score. The result showed that 3 students $(0.9 \%)$ were in summa cumlaude category, 152 students (44\%) were in cumlaude category, 175 students $(50,7$ $\%)$ were in very good category, 12 students $(3.5 \%)$ were in good category, and 3 students $(0.9$ $\%$ ) were in enough category. From the data, it can be concluded that most of students' academic achievement is above very good category. The distribution of the students' academic achievement is presented in the following table:

Table 4. Distribution of academic achievement

\begin{tabular}{cccc}
\hline Score Interval & Category & Frequency & Percentage \\
\hline 4.00 & Summa Cumlaude & 3 & $0,9 \%$ \\
\hline $3.51-3.99$ & Cumlaude & 152 & $44 \%$ \\
\hline $3.01-3.50$ & Very Good & 175 & $50,7 \%$ \\
\hline $2.51-3.00$ & Good & 12 & $3,5 \%$ \\
\hline $2.00-2.50$ & Enough & 3 & $0,9 \%$ \\
\hline Total & & 345 & $100 \%$ \\
\hline
\end{tabular}

Based on Pearson Product Moment Correlation Coefficient, the result indicated that there was a correlation between classroom environment and academic achievement. The correlation coefficient or the $r$-obtained (.296) was higher than $r$-table (0.1059). Then the level of probability (p) significance (sig.2-tailed) was .000. It means that $p(.000)$ was lower than .05. It can be inferred that the alternative hypothesis $\left(\mathrm{H}_{2}\right)$ is accepted and null hypothesis $\left(\mathrm{H}_{0}\right)$ is rejected. In other words, there was a positive correlation between classroom environment and academic achievement. Based on the interval coefficient by Cohen, Manion, and Marisson (2007), the correlation coefficient or the $r$-obtained (.296) indicates that the level of correlation between variables is slight correlation. 
Table 5. Correlations between classroom environment and academic achievement

\begin{tabular}{lrrrr}
\hline & & $\begin{array}{r}\text { Classroom } \\
\text { Environment }\end{array}$ & $\begin{array}{r}\text { Academic } \\
\text { Achievement }\end{array}$ \\
\hline Classroom_Environment & Pearson Correlation & 1 & $.296^{* *}$ \\
\cline { 2 - 5 } & \multicolumn{2}{c}{ Sig. (2-tailed) } & .000 \\
\cline { 2 - 5 } & $\mathrm{N}$ & 345 & 345 \\
\hline Academic_Achievement & \multicolumn{2}{c}{ Pearson Correlation } & $.296^{* *}$ & 1 \\
\cline { 2 - 4 } & Sig. (2-tailed) & .000 & 345 \\
\cline { 2 - 4 } & & $\mathrm{N}$ & 345 & \\
\cline { 2 - 4 } & & &
\end{tabular}

Since there was a correlation between classroom environment and academic achievement, it can be inferred that classroom environment has influence on students' academic achievement. Therefore, regression analysis was conducted to find out if classroom environment influenced academic achievement. The result of regression analysis is described in Table 6 below.

Table 6. Contribution of classroom environment on students' academic achievement

\begin{tabular}{|c|c|c|c|c|c|c|}
\hline \multirow[b]{3}{*}{ [odel } & & \multicolumn{5}{|c|}{ Standardize } \\
\hline & & \multirow{2}{*}{\multicolumn{2}{|c|}{$\begin{array}{r}\begin{array}{r}\text { Unstandardized } \\
\text { Coefficients }\end{array} \\
\text { B Std. Error }\end{array}$}} & $\begin{array}{r}d \\
\text { Coefficients }\end{array}$ & \multirow[b]{2}{*}{$\mathrm{t}$} & \multirow[b]{2}{*}{ Sig. } \\
\hline & & & & Beta & & \\
\hline \multirow[t]{2}{*}{1} & (Constant) & 2.648 & .140 & & 18.852 & .000 \\
\hline & Classroom_Environment & .005 & .001 & .296 & 5.739 & .000 \\
\hline
\end{tabular}

The results indicated that classroom environment influenced students' academic achievement with $\mathrm{t}_{\text {value }}(5.739)$ which was higher than $\mathrm{t}_{\text {table }}(1.967)$ and Sig.value $(.00)$ was lower than probability (.05). From the data above, it can be concluded that classroom environment significantly influenced the academic achievement of English Education Study Program Students of State Islamic University of Raden Fatah Palembang. In addition, to know the percentage of classroom environment influence on academic achievement, R-Square was obtained. The result of the analysis revealed that the $\mathrm{R}$ Square $\left(\mathrm{R}^{2}\right)$ was .088. It means that classroom environment gave effect in the level of $8.8 \%$ toward academic achievement. The percentage of the influence can be seen from Table. 7 below.

Table 7. The percentage of classroom environment contributing to students' academic achievement

\begin{tabular}{rrrrr} 
Model & R & R Square & Adjusted R Square & $\begin{array}{r}\text { Std. Error of the } \\
\text { Estimate }\end{array}$ \\
\hline 1 & $.296^{\mathrm{a}}$ & .088 & .085 & .27232 \\
\hline
\end{tabular}


Table 7. The percentage of classroom environment contributing to students' academic achievement

\begin{tabular}{rrrrr}
\hline Model & R & R Square & Adjusted R Square & $\begin{array}{r}\text { Std. Error of the } \\
\text { Estimate }\end{array}$ \\
\hline 1 & $.296^{\mathrm{a}}$ & .088 & .085 & .27232 \\
\hline
\end{tabular}

a. Predictors: (Constant), Classroom_Environment

In order to strengthen the value of this study, the interpretations were made based on the result of data analyses. According to the findings, there was a positive and significant correlation between classroom environment and academic achievement, and also an influence of classroom environment toward academic achievement of English Education Study Program Students of State Islamic University of Raden Fatah Palembang. In addition, the result of Pearson Product Moment Correlations showed that there was a positive correlation between classroom environment and academic achievement students of English Education Study Program at State Islamic University of Raden Fatah Palembang ( $r$ - 296). This means that classroom environment had slight relation to their academic achievement. Though it was a slight correlation; classroom environment can give an impact toward students' academic achievement. It is in line with Fraser (1998) who stated that the quality of the classroom environment is the significant determinant of students' learning. Similarly, Bennipal and Singh (2014) also found that there was a positive relationship between academic achievement and classroom environment among adolescents of schools of Ludhiana District. In addition, a study conducted by Akomolafe and Adesua (2015) showed that there was a significant relationship between classroom environment and the academic performance.

Besides, it also revealed that students' classroom environment gave slight influence on students' academic achievement. Students spend their time to learn mostly in the classroom. Classroom remains to be the main learning environment in an institution (Falsario, Muyong, Nuevaespana, 2014). Despite being the main learning environment, it does not guarantee that classroom environment will give more impact on students' academic achievement. In this study, classroom environment gave only $8.8 \%$ effect towards academic achievement. It means that from 345 students, classroom environment influenced 30 students' academic achievement, and $91,2 \%$ was influenced by other factors. Those factors are gender difference, teacher's education and teaching style, class environment, family education background (Mushtaq \& Khan, 2012), age, peer influences, course assessment, class attendance, class size and entry qualification (Daniel, 2016). In addition, Farooq, Chaudhry, Shafiq, and Berhan (2011) stated that not only environment and personal characteristics of learners that play important roles on their academic success but also socioeconomic status. Socioeconomic status is one of the most researched and debated factors among educational professionals that contribute towards the academic performance of students. The most prevalent argument is that the socioeconomic status of learners affects the quality of their academic performance. Moreover, the findings of research by Hijazi and Naqvi (2006) focused on student performance is affected by different factors, such as learning abilities because new paradigm about learning assumes that all students can and should learn at higher levels, but it should not be considered as constraint because there are other factors like race, gender, sex that can affect student's performance. Therefore, the influence of classroom environment toward students' academic achievement was not strong. Finally, this study found there was relationship and influence between classroom environment and academic achievement of English Education Study Program students of State Islamic University of Raden Fatah Palembang. 


\section{Conclusions}

From the findings and interpretations in discussed above, some conclusions could be presented. First, the correlation coefficient or the r-obtained (.296) was higher than $r$-table (0.1059), it means that the result indicated that there was a positive and significant relationship between classroom environment and academic achievement. Second, the findings revealed that there was a slight influence of classroom environment toward academic achievement of English Education Study Program Students of State Islamic University of Raden Fatah Palembang. It was shown that classroom environment gave only $8 \%$ contribution to their academic performance. So, it can be inferred that the lower classroom environment as perceived by the students, the lower their academic achievement would be.

\section{References}

Abrar, M., Mukminin, A., Habibi, A., Asyrafi, F., Makmur, M., \& Marzulina, L. (2018). “If our English isn't a language, what is it?” Indonesian EFL Student Teachers' Challenges Speaking English. The Qualitative Report, 23(1), 129-145. Retrieved from http://nsuworks.nova.edu/tqr/vol23/iss1/9

Abrar, M., \& Mukminin, A. (2016). International graduate classroom discussion engagement, challenges, and solving-strategies: Stories from Indonesian students in a United Kingdom university. Asia-Pacific Collaborative education Journal, 12(1), 5-20.

Akubue, A.U. (2001). Classroom organization and management: A 5-points strategy. Ibadan: Wisdom Publishers.

Akomolafe, C.O, \& Adesua, V.O. (2015). The classroom environment: A major motivating factor towards high academic performance of senior secondary school students in south west Nigeria. Journal of Education and Practice, 6(34), 17-21.

Ali, N., Jusoff, K., Ali, S., Mokhtar, N., \& Salamat, A. S. A. (2009). The factor influencing students' performance at University technology MARA Kedah, Malaysia. Canadian Research \& Development Center of Sciences and Cultures, 3(4), 81-90.

Ariesca, \& Marzulina, L. 2016. Teaching reading narrative text by using window notes strategy to the eighth grade students of SMP Muhammadiyah 4 Palembang. Edukasi: Jurnal Pendidikan dan Pengajaran, 3(1), 23-32.

Azkiyah, S.N., \& Mukminin, A. (2017). In search of teaching quality of student teachers: the case of one teacher education program in Indonesia. Center for Educational Policy Studies Journal, 7(4), 105-124.

Benipal, A. S., \& Singh, J. (2014). A study of academic achievement of adolescents in relation to their perception of classroom environment in Punjab. Educationa confab, 3(7), 18-26.

Brockman, M. S., \& Russell, S. T. (2012). Academic Success. Retrieved from http://classroom.leanderisd.org/users/0955/docs/academic success.pdf.

Bucholz, J.L., \& Sheffler, J.L. (2009). Creating a warm and inclusive classroom environment: Planning for all children to feel welcome. Electronic Journal for Inclusive Education, 2(4), 1-13.

Carpenters, B. O. (2006). Foundation of education, Benin: Ethiopia.

Cohen, L., Manion, L., \& Morrison, K. (6 $6^{\text {th }}$ Eds.). (2007). Research methods in education. New York, NY: Routlege.

Daniel, A. (2016). Gender effect on academic performance of junior high school athlestes in Ghana: A case study of Komenda, Edina, Eguafo, and Abirem municipality in central region. International journal of physical education, sports and health, 3(2), 355-364.

Daulta, M.S. (2008), Impact of home environment on the scholastic achievement of children. Journal of human ecology, 23(1), 75-77. 
Dewey, T. O. (2006). Infant and child in the culture of today. New York, NY: Harper and Row.

Farooq, M. S., Chaudhry, A. H., Shafiq, M., \& Berhan, G. (2011). Factors affecting students' quality of academic performance: A case of secondary school level. Journal of Quality and Technology Management, 7(2), 1-14.

Fraenkel, J. R., Wallen, N. E., \& Hyun. (8 ${ }^{\text {th }}$ Eds.). (2012). How to design and evaluate: research in education. New York, NY: McGraw-Hill Higher Education.

Fraser, B., \& Pickett, L. (2010). Creating and assessing positive classroom learning environments. Childhood Education, 3. Retrieved from http://www.highbeam.com

Fraser, B. J. (1998). Classroom environment instruments: Development, validity, and applications. Learning Environment Research, 1(1), 7-34.

Gazelle, H. (2006). Class climate moderates peer relations and emotional adjustment in children with an early history of anxious solitude: A child X environment model. Developmental Psychology, 42, 1179-1192.

Habibi, A., Sofwan, M., \& Mukminin, A. (2016). English teaching implementation in Indonesian pesantrens: teachers'demotivation factors. Indonesian Journal of English Teaching, 5(2), 199213.

Hannah, R. (2013). The effect of classroom environment on student learning (Honors thesis, Western Michigan University, USA). Retrieved from http://scholarworks.wmich.edu/cgi/viewcontent.cgi?article $=3380 \&$ context $=$ honors_theses.

Hadiyanto, Mukminin, A., Failasofah, Arif, N., Fajaryani, N., \& Habibi, A. (2017). In search of quality student teachers in a digital era: Reframing the practices of soft skills in teacher education. Turkish Online Journal of Educational Technology, 16(3), 71-79.

Haryanto, E., \& Mukminin, A. (2012). The Global, the National and the Local goals: English Language Policy Implementation in an Indonesian International Standard School. Excellence in Higher Education Journal, 3(2), 69-78.

Hisken, L. J. (2011). The correlation between self-esteem and student reading ability, reading level, and academic achievement. Master thesis, University of Central Missouri, Warrensburg, Missouri.

Hijazi, S. T \& Naqvi, S, M. M. R. (2006). Factors affecting students' performance a case of private colleges. Bangladesh e-Journal of Sociology, 3(1), 1-10.

Joanna, I. O. (2009). Relationship between students perception of psycho-social environment and achievement in geography.University of Nigeria, Nsukka, Nigeria.

Kamil, D., \& Mukminin, A. (2015). Indonesian Students' Multicultural Awareness in Homogeneously and Heterogeneously Populated Schools and Multicultural Education Policy. Asia-Pacific Collaborative Education Journal, 11 (1), 29-41.

Kaur, (2001). Academic achievement as resulted to achievement motivation at senior secondary level. Dissertation, Panjab University, Chandigarh.

Luschei, T. (2017). 20 years of TIMSS: Lessons for Indonesia. Indonesian Research Journal in Education $|I R J E|, 1(1), 6-17$.

MacAulay, D. J. (1990). Classroom environment: A literature review. Educational psychology, 10(3) 239-253.

Mokhtar, S. (2003). Classroom environment and academic performance at kolej Yayasan Pelajaran Mara Kuala Lumpur. Master thesis, International Islamic University Malaysia, Kuala Lumpur, Malaysia.

Mukminin, A., Kamil, D., Muazza, M., \& Haryanto, E. (2017). Why teacher education? Documenting undocumented female student teachers' motives in Indonesia: A case study. The Qualitative Report (USA), 22(1), 309-326. 
Mukminin, A., Rohayati, T., Putra, H. A., Habibi, A., \& Aina, M. (2017). The Long Walk to Quality Teacher Education in Indonesia: Student Teachers' Motives to become a Teacher and Policy Implications. Elementary Education Online, 16(1), 35-59.

Mukminin, A., \& McMahon, B.J. (2013). International Graduate Students' Cross-Cultural Academic Engagement: Stories of Indonesian Doctoral Students on American Campus. The Qualitative Report, 18 (69), 1-19.

Mukminin, A., Haryanto, E., Makmur, Failasofah, Fajaryani, N., Thabran, Y., \& Suyadi. (2013). The achievement ideology and top-down national standardized exam policy in Indonesia: Voices from local English teachers. Turkish Online Journal of Qualitative Inquiry, 4(4), 19-38.

Mukminin, A., Ali, Rd. M., \& Fadloan, M.J. (2015). Voices from within: Student teachers' experiences in english academic writing socialization at one Indonesian teacher training program. The Qualitative Report, 20 (9), 1394-1407.

Mukminin, A., Muazza, Hustarna, \& Sari, S.R. (2015). Stories from the frontlines: In-service teachers' demotivating factors and policy recommendations. International Journal of Academic Research in Education, 1(2), 40-52. DOI: 10.17985/ijare.56085.

Mushtaq, I. \& Khan, S.N. (2012). Factor Affecting Students' Academic Achievement. Global Journal of management and business research 12(9), 17-22.

Nuthanap, G. (2007). Gender analysis of academic achievement among high school students. Master thesis, Dharwad university of agricultural sciences, Dharwad.

Picus, L. O., Marion, S. F., Calvo, N., \& Glenn, W. J. (2005). Understanding the relationship between student achievement and the quality of educational facilities: Evidence from Wyoming. Peabody Journal of Education, 80, 71-95.

Sánchez-Escobedo, P., \& Hollingworth, L. (2017). A model for evaluation of rural schools in developing countries. Indonesian Research Journal in Education |IRJE |, 1(1), 18-28.

Siahi, E. A, \& Maiyo, J. K. (2015). Study of the relationship between study habits and academic achievement of students: A case of Spicer higher secondary school, India. International Journal of Educational Administration and Policy Studies, 7(7), 134-141.

Suleman, Q. \& Hussain, I. (2014). Effects of classroom physical environment on the academic achievement score of secondary school in Kohat Division, Pakistan. International Journal of Learning and Development, 4(1), 71-82.

Talton, E. L, \& Simpson R. D. (1987). Relationship of attitude toward classroom environment with attitude toward achievement in science among tenth grade geography students. Journal of Research in Science Teaching, 24, 507- 526.

Treagust, D. F. \& Fraser, B, J. (1986). Validity and use of a classroom environment instrument for higher education. National Association for Research in Science Teaching, San Francisco.

Wei, L. S., \& Elias, H. (2011). Relationship between students' perceptions of classroom environment and their motivation in learning English language. International Journal of Humanities and Social Science, 1(21), 240-250.

William, D. L. (1997). Evaluating the university environment from a comprehensive system perspective: The college/ university environment scale. Master thesis, Acadia University, Canada.

Yan, X. (2006). Teacher talk and EFL in university classrooms. Dissertation Thesis, Chongqing Normal University and Yangtze Normal University, China.

Ziegler, S.A., Cheryan, S., Plaut, V.C., \& Meltzoff, A. N. (2014). Designing classroom to maximize students achievement. Behavioral and Brain Sciences, 1(1) 4-12. 